\title{
GOODS AND SERVICES TAX (GST): THE IMPORTANCE OF COMPREHENSION TOWARDS ACHIEVING THE DESIRED AWARENESS AMONG MALAYSIAN
}

\author{
Rani Diana Othman*, Nur Farahah Mohd Pauzi, Siti Anis Nadia Abu Bakar, Afidah Sapari \\ Mohd Syazwan Karim \\ Faculty of Accountancy, Universiti Teknologi MARA Melaka
}

\begin{abstract}
In line with the implementation of value added tax (VAT) by 160 countries, Malaysia has taken its own path with the introduction of goods and services tax (GST) starting from 1 April 2015 to replace its previous tax system. This new tax system has been announced on 25 October 2013, which has given about 17 months for businesses and people in Malaysia to make a complete preparation for GST. GST is proven to be the fairer tax system to overcome the previous one which was not only limited in scope, but also came with a number of inherent weaknesses. Therefore, in order to achieve the desired awareness regarding GST, it is essential that all Malaysians have the required level of understanding in terms of its concepts, scopes, charges and mechanisms. This paper discusses the benefits of GST for the nation in the long run as well as the negative perceptions from the public. This should reveal the additional steps to be taken by the regulators in ensuring a better comprehension of this new tax system among the citizens as a support for the government's tax reform, which has been programmed for Malaysia to move towards a high-income nation.
\end{abstract}

Keywords: Goods and Services Tax, Sales and Services Tax, Tax Reform

\section{INTRODUCTION}

The implementation of Goods and Services Tax (GST) in Malaysia has been commented by many parties including from the Taxand Malaysia Sdn Bhd Chairman, Dr Veerinderjeet Singh, who said that, "Malaysia is currently in a period of uncertainty and it was not the right time to reduce income tax, even with GST in place" (Singh, 2013). Such comment was made since Malaysia has been facing fiscal deficit without a booming economic climate and slower future growth for a number of previous years. The following were 2012 Malaysia's fiscal positions, which have been highlighted as vulnerable indicators of Malaysian economic condition by Othman \& Mirakhor (2012): 
Table 1: Fiscal position of Malaysia on 2012

\begin{tabular}{|c|c|c|}
\hline & Weak fiscal position & Malaysia's position \\
\hline \multirow[t]{2}{*}{1.} & $\begin{array}{l}\text { Overall fiscal balance as } \\
\text { a share of gross } \\
\text { domestic product } \\
\text { (GDP) }\end{array}$ & $\begin{array}{l}\text { 1. Persistent deficit for the past } 15 \text { years, where Malaysia's budget deficit in } 2011 \\
\text { stood at } 5.3 \% \text { of GDP, while national debt was } 53 \% \text { of GDP. } \\
\text { 2. Malaysia is still running fiscal deficits even when Malaysia's economy is } \\
\text { growing by more than } 5 \% \text { in } 2010 \text {. }\end{array}$ \\
\hline & & (Debt and growth figures based on www.tradingeconomics.com) \\
\hline \multirow[t]{2}{*}{2.} & $\begin{array}{l}\text { Net financial debt as a } \\
\text { share of GDP }\end{array}$ & $\begin{array}{l}\text { 1. National debt was reported to be } 53 \% \text { of GDP in } 2011 \text { and improved to } 52 \% \text { in } \\
2012 \text {. } \\
\text { 2. However, it was projected to climb to } 54 \% \text { in } 2013 \text {. } \\
\text { 3. The increase in issuance of government securities has led to an increase in } \\
\text { interest payment from } 7.6 \% \text { in } 2012 \text { to } 10.3 \% \text { in } 2013 \text { which considered a } 36 \% \\
\text { of debt service ratio (Bank Negara Report, } 2011 \text { ). }\end{array}$ \\
\hline & & (External debt service ratio as percentage of export goods and service) \\
\hline \multirow[t]{2}{*}{3.} & $\begin{array}{l}\text { Sizeable uncovered } \\
\text { contingent liabilities }\end{array}$ & $\begin{array}{l}\text { The size of debts is estimated to be approximately } 67 \% \text { of GDP if contingent liabilities } \\
\text { are considered. }\end{array}$ \\
\hline & & $\begin{array}{l}\text { (Based on contingent liability of RM117 billion reported in the Malaysia Insider, } 20 \\
\text { June 2012) }\end{array}$ \\
\hline \multirow[t]{2}{*}{4.} & $\begin{array}{l}\text { Large share of non- } \\
\text { discretionary spending } \\
\text { and/or transfer }\end{array}$ & $\begin{array}{l}\text { Incomparable of operating expenditure to development expenditure. In 2010, operating } \\
\text { expenditure was RM152 billion compared to development expenditure of RM45 billion. }\end{array}$ \\
\hline & & $\begin{array}{l}\text { The operating expenditure has increased to RM } 182 \text { billion in } 2012 \text { compared to only } \\
\text { RM } 48 \text { billions of development expenditure of the same year. This shows that Malaysia } \\
\text { is running deficits to fund spending which does not add value or productivity in the long } \\
\text { run. }\end{array}$ \\
\hline
\end{tabular}

Due to weak fiscal positions mentioned above, suggestions have been made to improve the Malaysian economic conditions. A short term fiscal policy was proposed to be designed by taking into consideration the review of the sustainability indicators and the role strengthening of the long-term estimates (Abdullah, Muszafarshah \& Dahalan, 2012). The objective of developing the fiscal policies by governments across the world is to boost the economic condition and the policy, which can either improve the usage of expenditure or revenue collection. Othman \& Mirakhor (2012) proposed a framework focusing on a tax structure that can improve the revenue and the public sector financing which mobilises non-debt-creating sources to finance development expenditure. Another suggestion was also made by Professor Datuk Muhammed Ariff, a renowned Malaysian economist, in his statement as quoted by The Star, on January 7, 2012, "To balance the books, the Government must rein in its operating expenditure and introduce tax reform". This is to confirm that a policy reform needs to be considered by looking at a simpler structure, where the levy of tax is based on the ability to pay.

One of the major tax reforms by the government of Malaysia was the introduction of GST, which has been implemented on April 1, 2015 with an intention to replace the Sales and Service Tax (SST). SST that has been used in the country for several decades was a form of indirect tax imposed on "taxable services" and "taxable goods" which were strictly prescribed by the act (Sales Tax Act 1972 and Service Tax Act 1975). Sales tax is operated in the same negative concept as GST, where all goods were subject to it unless specifically prescribed. Unlike the former, service tax operated in the opposite concept where only services specifically prescribed by the act were taxable. Both taxes were known as single stage tax, where sales tax became due and payable when there was a sale or disposal, and service tax was only due when payment was received. However, if payment was not received, the service tax was accounted for at the end of the 12-month period from the date of invoice issued. 
GST is an indirect tax administered by The Royal Malaysian Customs Department (RMCD) and governed by the Goods and Services Tax Act 2014. GST is also commonly referred to as Value Added Tax (VAT) and collected at various stages of production. The collection of GST is based on output tax, which will be charged by the supplier on taxable goods as well as services, and input tax, which is incurred by the businesses on goods and services purchases. According to Tan Sri Ariffin Zakaria (2010), Chief Justice of Malaysia, the introduction of GST will be a major tax reform in the country, which is able to enhance the capability, effectiveness, and also transparency of the tax administration and management. This new tax system is also expected to prepare savings for the country should it experience inflation in the future (Palil \& Ibrahim, 2011). Their research has also highlighted that the most salient feature of GST is its regressive nature with respect to income.

GST has been implemented in nearly 160 countries with different experiences of achievements and obstacles. Our neighbouring country, Singapore, has adopted GST on April 1994 and has succeeded based on advantages such as the fact that the tax is on consumption, which encourages savings and investments, rewards enterprise, and strengthens economic resilience. The system is also claimed to stimulate the competitiveness of a country (Low \& Carol, 1994). As for India, after various trials in reforming the indirect tax structure, its government did not encounter many problems since there were no differences in term of levying the tax towards the GST as both are imposed on the same rate (Syed, Amit \& Ravindra, 2013). Implementation of GST in New Zealand showed that the original rate in 1986 was 12.5 percent and increased to 15 percent in 2010. The advantage of GST in New Zealand is that the "zero-rate" is charged on businesses exporting goods and services, which permits those businesses to claim back the input tax as GST return because the non-New Zealand based consumers do not pay the tax.

Despite the initiative of introducing GST as an effort to reduce federal government deficit, it is aimed to diversify the nation's sources of income, provide a constant flow of earnings as to elevate public service, and also improve economic stability (McGowan \& Billings, 1997). Overall, Malaysians are not fully convinced with the new tax scheme. Csontos, Kornai and Toth (1998) highlighted that such a perception was due to pessimistic view, which refers to citizens who have overestimated tax burden or inaccurately estimated public service burden, with the tax imposed to the public. This has further caused a misconception on tax requirements, in particular towards the recently introduced tax reform. Therefore, having sufficient understanding of the new system is essential for the taxpayers to support GST as a way to overcome the national fiscal deficit problem and economic downturn.

\section{GST TO OVERCOME THE WEAKNESSES OF SST}

\section{Malaysian Indirect Tax System under the Previous Regime of SST}

Indirect tax was considered as the most convenient tax for the purpose of revenue generation compared to the direct tax from the public (Barjoyai, 1993). Malaysian indirect tax structure consisted of the collection of various revenues such as excise duties on alcohol, tobacco and a few other products, import duties and stamp duties, export duty, levy, as well as others. However, the most broadly based indirect tax in Malaysia was the SST (Kasipillai \& Sinnakkannu, 2008). Sales tax was governed by the Sales Tax Act of 1972 while Service Tax was governed by the Service Tax Act of 1975.

Throughout the years, SST became the important source of revenue to the country. The source of revenue estimates from indirect taxes of the federal government are presented in Table 1 
below, which shows the source of revenue from SST comprising of 45 percent in 2013 and 46 percent in 2014 from the total indirect tax collected.

Table 2: Estimates of Federal Government's Revenue (2013 and 2014)

\begin{tabular}{|c|c|c|c|c|}
\hline Source of revenue & (RM million) & $\begin{array}{c}2013 \\
\text { (RM million) } \\
\end{array}$ & (RM million) & $\begin{array}{c}2014 \\
\text { (RM million) }\end{array}$ \\
\hline Direct Tax & & 127,020 & & 133,148 \\
\hline Indirect Tax & & 36,486 & & 38,822 \\
\hline - Export duty & 2,099 & & 2,105 & \\
\hline - Import duty & 2,417 & & 2,502 & \\
\hline - $\quad$ Excise duty & 12,728 & & 13,442 & \\
\hline Sales tax & 10,199 & & 10,986 & \\
\hline - $\quad$ Service tax & 6,161 & & 6,810 & \\
\hline - Levy & 150 & & 150 & \\
\hline - Others & 2,732 & & 2,827 & \\
\hline
\end{tabular}

Non tax revenue

54,428

50,627

Source: Estimates of Federal Government's Revenue Report (2014), Ministry of Finance

SST was a single stage ad valorem tax imposed based on the respective scope of charges that were accountable to the Royal Malaysian Customs Department (RMCD). The sales tax was imposed on taxable locally manufactured and/or imported goods. It was considered as a consumption tax, and therefore, under the system, the onus was on the manufacturers to levy charges and collect tax from their customers (Mansor, Tayib \& Yusof, 2005). For imported goods, sales tax was collected from the importers upon the release of goods from customs control, which was computed, based on the value of taxable goods sold, used or disposed of, or imported. With effect from January 2003, the valuation method for locally manufactured goods was based on the transaction value as determined by the World Trade Organisation's (WTO) method of valuation (Mansor et al., 2005). Furthermore, starting from October 31, 2012, the sales tax rate varied from 0 percent, 5 percent, and 10 percent to 20 percent, depending on the categories of goods subject to sales tax. Certain goods such as food and fruits for general lifestyle were nil rates on sales tax, food and fruits for expensive lifestyle, as well as beer and wine were 5 percent on sales tax, whereas other goods were taxed standard rate of 10 percent (Choong, 2014). Specific sales tax rates were also imposed on certain classes of petroleum such as refined petroleum, diesel fuel, gas oil, and liquefied natural gas (Sapiei \& Abdullah, 2015).

Section 13 of Sales Tax Act 1972 stated that every manufacturer of taxable goods shall apply for a sales tax license (JKED No. 1) (Choong, 2014). However the exemption from licensing applied to manufacturers whose respective turnovers were below RM100,000 and contractors whose respective turnovers were below RM20,000. Apart from exported goods, an exemption from sales tax also applied to goods listed in Schedule A to the Sales Tax (Exemption) Order 1980 (Kasipillai \& Sinnakkannu, 2008), goods listed in Schedule B of the Sales Tax (Exemption From Licensing) Order 1997, Free Zone (Section 2A), licensed warehouse and licensed manufacturing warehouse (s2B), as well as goods manufactured in Labuan, Langkawi and Tioman (Choong, 2014).

The service tax had to be charged and levied on the taxable services provided by the taxable persons based on various rates for services such as restaurants, hotels, and health centres. It had been expanded to include other professional services such as lawyers, valuators, forwarding agencies, insurance companies, accountants, engineers, architects, and private hospitals. It also included the telecommunications services, security guard services, parking services, car rental and other taxable services, whose respective annual turnovers reached the threshold limit between RM150,000 and RM300,000, depending on the group of taxable 
persons (Kasipillai \& Sinnakkannu, 2008; Choong, 2014). The service tax applied at a single rate of 6 percent (with effect from 1 January 2011) throughout Malaysia except Langkawi, Labuan, Tioman, and Joint Development Area as defined in s2 Malaysia - Thailand Joint Authority Act 1990 (Choong, 2014).

\section{Weaknesses of SST to be overcome by GST}

The new regime of GST needs to be implemented in Malaysia due to the weaknesses of the previous SST system as highlighted by the former Deputy Minister of Finance, Datuk Chan Kong Choy (Mansor et al., 2005), who disclosed the fact that tax authorities were unable to collect a total of RM4.2 billion of taxes inclusive of the unpaid sales tax of RM75.7 million, service tax of RM46.8 million, custom duties of RM46.7 million, and excise duties of RM0.57 million as of April 2002. Furthermore, based on RMCD's statistics, since 2005 until 31 December 2008, RM335.95 million of taxes were not collected or failed to be paid by the taxpayers (Bidin, Shalihen, Shamsudin M \& Othman, 2011). Kasipillai \& Sinnakkannu (2008) stated that the sales tax was a complex tax on the manufacturing of goods and the importation of manufactured goods. The complexity included the exemption mechanism since it depended on the turnovers of licensed manufacturers and the types of manufacturing activity. Besides that, the service tax was also found to have an arbitrary effect on consumers' prices. The tax only applied to a set of defined activities classified as "taxable services" whose value had exceeded a certain annual threshold.

The weaknesses of the SST also included high incidence of tax avoidance, double taxation along the value-chain that pushed prices up, as well as extensive exemptions and this explained the low collection of revenue from SST (Zhou, Tam \& Heng, 2013). From the total estimation of the federal government revenue in 2013 , sales tax represented only 4.6 percent while service tax represented only 3.1 percent, whereby in total, SST contributed only 7.7 percent of revenue. Therefore a new form of tax was needed to both expand the tax base that would increase the revenue collection of the country, as well as gradually replace oil-related revenue and excise duties as it was already known that the major source of government revenue has come from petroleum and taxation. The increase in revenue for the country is important to finance the government expenditure as well as to help providing more socio-economic programmes (Alappatt \& Shaikh, 2014).

\section{Indirect tax under the new regime of GST}

GST is a broad-based consumption tax on which a person pays when he or she spends money (Alappatt \& Shaikh, 2014; Sapiei \& Abdullah, 2015). More than 120 countries have already implemented GST (Alappatt \& Shaikh, 2014). It is considered as a multi-staged value added tax, which means tax is charged on any taxable goods and services at all levels in the supply chain, namely production, manufacturing, wholesale, retail, and through to the final consumer. In contrast, the previous sales tax was imposed on the manufacturer before the service tax was imposed on the consumer at the point of purchase. Thus, double taxations in SST pushed up prices and reduced consumer welfare (Zhou et al., (2013). However, since GST is collected and paid at all stages of the supply chain, the registrants will charge and collect the tax on taxable goods and services they provide, which are the taxable supplies. The GST paid on their purchases, known as input tax credit, will be set off from the GST they charged and collected, that is the output tax. If the output tax exceeds the input tax, the difference is to be remitted to 
the customs department. On the other hand, if the output tax is less than the input tax, a refund will be given by the Customs authorities (Alappatt \& Shaikh, 2014).

A "taxable person" in GST means a person registered under Section 19, Goods and Services Tax Act 2014, "goods" means any kind of moveable and immovable properties but excludes money except a bank note or coin, whereas "supply" means all forms of supply, including supply of imported services [S.4(1)] (Sapiei \& Abdullah, 2015, p 641). Thus GST can only be charged on the taxable supply made by a registered business. A supply must either be standard rated or zero-rated; exempt and out of scope supplies that are not taxable supplies (Department RMC, 2014).

The current standard GST rate is 6 percent and it is collected by the business and paid to the government, whereas zero-rated supply is applicable to any goods or services determined by the Minister [GST (Zero-Rated Supply) Order 2014] and to any goods if they are exported (Department RMC, 2014). For the zero-rated supply, a registered business cannot charge a tax to the customer, but it can claim credit for the GST paid on their business inputs. Mostly, the items under zero-rated supply comprise of basic foods such as rice, sugar, flour, fish, chicken, cooking oil, and egg. Meanwhile, exempted supply refers to non-taxable items that are not subject to GST [GST (Exempt Supply) Order 2014] such as public transportation, health services, public education, as well as funeral services. Out of scope supply consists of any items that are considered as out of scope and not subject to GST such as supply by state and federal government, supply by a business below the RM500,000 threshold, supply of goods outside Malaysia, supply of services outside Malaysia by a person not in Malaysia, and supply of goods and services made within tax-free areas in Malaysia, namely Labuan, Langkawi and Tioman.

According to Zhou et al., (2013, p.2), GST offers a single unified system where the tax burden is equally shared between the services and the manufacturing industries, whilst simultaneously broadening the tax base. This will help to minimise tax exemptions as well as the compounding effects of pyramiding tax, tax erosion, transfer pricing, and value shifting. It will also ensure a level of stability, as GST is less susceptible to the fluctuations inherent in the commodity markets. Besides that, GST is claimable by the businesses, thus the lesser incentive to evade tax.

\section{WHY GST?}

\section{Improved Standard of Living towards Building the Nation}

Taxation is a very important element and a major source of revenue for the economic development and growth. For most countries, the revenue is generated through taxation, that comprises of direct and indirect tax. The contribution to national fiscal revenue through the implementation of VAT by the developing countries, such as China, is much more than the developed countries (Xing \& Whalley, 2014) and VAT has become the major source of tax revenue for China ( $\mathrm{Liu} \& \mathrm{Lu}, 2015$ ). In Malaysia, the implementation of GST is aimed to improve the revenue collection and reduce the nation's growing budget deficit, which ultimately could increase the standard of living among Malaysians as a whole.

From 1960s to 1970 s, only a few countries adopted GST and most of them still relied on the direct taxes such as corporate tax and personal income tax. A very high tax rate was set in the early 1970s, such as United Kingdom with 75 percent, South Korea with 70 percent, and Taiwan with 60 percent (Low \& Carol, 1994). As a consequence, high corporate taxes tend to 
discourage initiatives of foreign investors to conduct international trade with those countries. According to Low \& Carol (1994), one of the advantages for the implementation of GST in Singapore is its help in raising the national income. On the other hand, among the reasons for the implementation is to sustain the lower corporate tax rate in the country. Therefore, this shall inculcate the spirit of entrepreneurship among Singaporeans, which in turn will add values to its business environment and further attract foreign investors. Besides that, the implementation of GST could reduce the reliance on direct taxation as a main source of revenue. GST clearly could be a more stable source of revenue, enabling the government to channel back the benefits to the people. Therefore, the tax reform program adopted by the Malaysian government intends to earn a more stable income and improve standard of living among Malaysians. It is indeed a good economic development strategy in moving towards a high-income nation by the year 2020.

\section{Enhanced Compliance}

Since the Malaysian government introduced GST to replace SST, it has created an integrated system that would enhance the level of conformity among the tax payers. In the 2005 budget speech, the former Prime Minister, Tun Abdullah bin Haji Ahmad Badawi, mentioned that GST could improve tax compliance:

“... The government proposes to replace both of these taxes (Sales Tax and Service Tax) with a single consumption tax, based on the value-added concept. The new tax, known as the Goods and Services Tax (GST), will be more comprehensive, efficient, transparent and effective, thereby enhancing tax compliance..." (KPMG, 2013)

Previously, there were two separate acts in governing the sales and service tax, which were both handled by the RMCD. Therefore, it indicated a complex system of laws and regulations that caused a decrease of compliance among the tax payers. Initially, Malaysians showed a resistance towards GST implementation as the businesses needed to adapt with the changes in administration works that consequently incurred high cost. However, the government has taken significant steps to enhance the tax compliance by ensuring that all businesses between the thresholds have registered as GST registrants and accordingly update their accounting systems, providing the necessary trainings to those companies to assure a thorough understanding of GST key element that include the concepts, scopes, charges, and mechanisms, as well as offering advices and close monitoring on the treatment of transitional issues upon the implementation (malaysia-gst.my). Hence, it is a good effort of the Malaysian government to implement GST under the tax reform program as it enhances tax compliance and reduce tax avoidance nationwide.

\section{Fair Pricing to Consumers}

The supply chain network for business transactions would usually consist of manufacturers, suppliers, warehouses, distribution centres, dealers, and more (Zhang \& Huang, 2014). According to Xing \& Whalley (2014), the government will levy the VAT to the value added at each of the chain in order to avoid double taxation. Therefore, the net tax payable would represent the one on the value-added goods processed and distributed or services rendered (Carvalho \& Lian, 2010). The implementation of GST in Malaysia is also designed to eliminate double taxation under the previous indirect tax charges of SST so that consumers will pay fairer prices for most goods and services. 
After the implementation of GST, 22 products which were previously subject to SST have been exempted from the GST. While 273 products which were earlier imposed with SST of 10 percent are now subjected to the GST of 6 percent. Nevertheless, the main problem to be resolved is the traders' manipulation of the prices (The Star Online, May 2015). GST would no longer be an issue to the consumers once the prices of all consumers' products could be controlled and stabilised.

\section{Greater Transparency}

GST is designed to benefit consumers unlike the previous SST whereby they will exactly know whether the goods and services are subject to tax and the prices stated conform to the specified rates. Accordingly, it would reveal the hidden tax by the manufacturers (Whalley \& Fretz, 1990), which ultimately could increase on the competitiveness among the businesses. According to Keen \& Lockwood (2010), VAT has been introduced as part of a program that modernises tax administration. It develops self-assessment method, which would reduce the difficulty in administration and compliance. Therefore, businesses become the tax collectors of GST until the final remittance to the RMCD after setting off the correct amount of input tax credit. A strict adherence is required relating to timing and remittance as well as invoicing requirements (Beh \& $\mathrm{Ng}, 2013$ ). This is essential to reach the neccessary level of transparency in order to overcome the previous tax system that was vulnerable to evasion and avoidance.

In Malaysia, a notice is displayed at all supermarkets to help customers identify the goods with 6 percent GST, those with zero-rate, and items that have been exempted from GST. This will help customers to plan their spending, thus avoiding unnecessary payment on indirect tax. In addition, each of the transactions made by the customers will be accompanied by the simplified tax invoice as reference. Under the previous tax regime of SST, the final consumers would not know the amount of indirect tax they had to pay as the charges had been included in the final prices of goods and services, with no detail stated on the receipt of purchase (Malaysia Kini, 2015). The disclosure of indirect tax is essential for customers to realise that GST is a compulsory consumption tax and they have no choice but to pay as per what they consume (The Star Online, April 2015).

\section{NEGATIVE PERCEPTION OF GST}

\section{Increase in Price for Goods and Services}

Consumers are always concern that the implementation of GST or VAT will cause the price to hike up (Mohd Rashid \& Shaik Asgar, 2014). However, the implementation of VAT in Australia showed no significant difference in the price within eight capital cities (Valadkhani \& Layton, 2004). On the other hand, in Canada, the price only hiked up once, but not continuously after the implementation of VAT (Dombrovski \& Hodžić, 2010). Even though there was an increment in price after the implementation of GST due to the unstable transitional stage from the previous tax system to the new tax system, Singapore has proven that they can maintain the inflationary pressure from rising up (Palil \& Ibrahim, 2011).

According to Deputy Minister of Finance, Datuk Haji Ahmad Maslan, the implementation of GST will not increase prices, but further reduce or retain them. This has been proven with the effort by one of the biggest grocery and merchandise retailers in Malaysia, Mydin Mall, that managed to maintain the same prices as well as announcing the absorbtion of indirect tax for the products which have been charged with GST (Malaysia Kini, 2015). The decision of GST 
absorption by Mydin Mall has been followed by many grocery and merchandise retailers as well as other businesses in Malaysia. As a result, there has been an increased competitiveness in the market that would continue in the long run.

\section{Roles of Tax Authority}

A few days after the implementation of GST in Malaysia, the news media reported drastically increased prices for consumers' products. This had happened due to the greed of businessmen, traders, and hawkers. Consequently, various complaints were recorded over seven days of implementation whereby the Domestic Trade, Cooperatives, and Consumerism Minister had received about 2,833 complaints on price increase in the market (Bernama, April 2014). This has aroused a curiosity among Malaysians on the role of tax authority as well as the government in handling these issues. They were indeed very intense at the beginning of GST implementation, subsequent to the political issues related to the new system.

In order to manage the problem, the Prime Minister, Dato' Seri Mohd Najib bin Tun Abdul Razak, has set up a special court of anti-profiteering in each capital state. The court handles special cases related to any offences by profiteers who exploit GST by unreasonably increasing the prices of goods and services (Bernama, June 2015). This is indeed an essential step to show the comprehensive efforts by the government to overcome the issue of profiteering at the beginning of GST implementation. Besides the courts, the fine and punishment charged on those convicted guilty indicated the severity of the crime. Any individuals that make unreasonable profits in selling or supplying goods are liable to a fine not exceeding RM100,000 or to imprisonment not exceeding three years, or both. Meanwhile, for any companies that are guilty of the same offences, they may be fined up to RM500,000 for the first offence and RM1,000,000 for the subsequent offence (The Star Online, March 2015). This is an indirect yet significant effort by the government to warn the public on the compliance issue.

\section{Administrative Problem}

The administrative problem lies within the complexity of the documents involved. GST is totally a new tax system which requires details of specific information on each part of the distribution channel. Therefore, a lot of documents are needed to cope with the procedures and guidelines in this new system. Nevertheless, according to Juddoo (2014), GST is a simple tax system that is essential for a better understanding by individuals and corporate taxpayers. A simple system also means fewer resources that are still able to effectively manage socially unproductive activities such as tax planning and litigation.

In particular, the administrative issues arise due to the unfamiliarity with the new system. This is a common problem faced by any organisations. Therefore, they may need time not only to familiarise themselves with the whole system, but also to reassess their approaches in managing the emerging issues. The understanding of how GST will affect their production processes will specifically help them in dealing with the compliance matters. Meanwhile, the government has undertaken the proactive measures by providing a free seminar to those taxable suppliers (www.customs.gov.my) as well as allowing them to claim for a special deduction under corporate taxation. All the training fees are claimable under Human Resources Development Fund's Scheme for attending a private training organised by a professional body in order to gain more knowledge and new adjustment for GST accounting treatment (Palil \& Ibrahim, 2011). 


\section{CONCLUSION}

GST is the new regime of indirect tax which differs significantly from the previous system. It brings a fundamental conversion to a multi-stage consumption tax, with vast procedural differences. This new approach covers from administrative matters including registration and invoicing, to penalty and interest rates. Such an overhaul will undoubtedly change the landscape of the commercial operation in Malaysia. In order to ensure the success of this modern consumption tax in the country, several recommendations have been made, such as, firstly, raising awareness on the exemption list and limit the expansion of the list; secondly, strengthen the cooperation with local consumer societies in order to fight profiteering activities; thirdly, commit to a five-year timeline and review GST with possibility of raising the rate by the year 2020; and finally, enhance the campaign on the importance of reducing budget deficit in order to raise public acceptance on arising issues (Zhou, Tam \& Heng-Contaxis, 2013).

However, the most important factor to be considered is to solidify the comprehension among the public towards the scopes, charges, and mechanisms of the new GST system. Mohani (2003) and Tan \& Chin-Fatt (2000) have asserted that the ways to increase public awareness is through tax knowledge that can be imparted by a general understanding on the tax regulations. Therefore, the government must put extra efforts in order to ensure that Malaysian taxpayers truly understand GST and gather their commitment of acceptance. In conclusion, a further research needs to be done in order to investigate the sufficiency of GST awareness campaign conducted by the government through various mass and social media. It is also claimed that the taxpayers' level of awareness has been associated with their tax knowledge (Palil \& Ibrahim, 2011). Future research should also evaluate the efficacy of this tax reform in terms of its ability in enhancing the transparency of Malaysian tax administration and management. The most important aspect is that whether this new tax system is able to improve the nation's economic condition in preparing Malaysia to be a developed country by the year 2020 .

\section{REFERENCES}

Abdullah, H., Muszafarshah, M. M. \& Dahalan, J. (2012). An empirical study on fiscal sustainability in Malaysia. International Journal Academic Research in Business and Social Sciences, 2(1), 72-90.

Alappatt, M. \& Shaikh J. M. (2014). Forthcoming procedure of goods and service tax (GST) in Malaysia. Issues in Business Management and Economics, 2(12), 210-213.

Bank Negara Malaysia (2011). Bank Negara Malaysia Annual Report 2011.

Beh, Y. \& Ng, K. (2013). Implementation of goods and services tax in Malaysia. Client Alert, Wong and Partners, Member Firm of Baker and Mckenzie International.

Bernama (2014). 98 Offences recorded since implementation of GST, April 7. Retrieved from http://www.bernama.com.

Bernama (2015). Najib visits anti-profiteering operations centre at KPDNKK, June 29. Retrieved from http://www.bernama.com. 
Bidin, Z., Shalihen, M. S., Shamsudin, F. M. \& Othman, Z. (2011). Factors influencing intention to comply with local sales tax in Malaysia. SSRN Electronic Journal.

Carvalho, E. \& Lian, Z. (2010). The impact of goods and services tax on the pattern of Canadian concumer spending and saving. The Journal of Economic Asymmetries, 17(1), 123-136.

Choong, K.F. (2014). Malaysian taxation: Principles and practice. 20th Edition, Malaysia: Infoworld.

Csontos, L., Kornai, J. \& Toth, I. G. (1998). Tax awareness and reform of the welfare state: Hungarian survey result. Economics of Transition, 6(2), 287-312.

Department RMC (2014). "About GST" What is GST. Retrieved from http://gst.customs.gov.my/en/gst/Pages/gst wi aspx.

Dombrovski, R. \& Hodžić, S. (2010). Impact of value added tax on tourism, The International Business and Economics Research Journal, 10, 131-138.

http://malaysia-gst.my/

http://www.customs.gov.my

Juddoo, K. (2014). The compliance cost of value added tax (VAT): The case of the republic of Mauritius. eJournal of Tax Research, 12(2), 499-521.

Kasipillai, J. \& Sinnakkannu, J. (2008). Distributive effects of the introduction of GST in Malaysia, International VAT Monitor, 359-366.

Keen, M. \& Lockwood, B. (2010). The value added tax: Its causes and consequences. Journal of Development Economics, 92, 138-151.

KPMG (2013. GST in Malaysia.

Liu, Q. \& Lu, Y. (2015). Firm investment and exporting: Evidence from China's value-added tax reform. Journal of International Economics.

Low, S. P. \& Carol, P. W. L. (1994). Implementation of the goods and services tax (GST) in the Singapore construction industry. Journal of Property Finance, 5(3), 41-58.

Malaysia Kini (2015). About Malaysia’s GST. Retrieved from http://aboutgst.malaysia.com.

Mansor, M., Tayib, M. \& Yusof, R. (2005). Malaysian indirect tax administration system: An analysis of efficiency and taxpayers' perceptions. IJMS, 12 (2), 19-40.

McGowan, J. R. \& Billings, B. A. (1997). An analysis of the European community VAT: Implication for U.S tax policy. Journal of Accounting, Auditing and Taxation, 6(2), 131-148.

Mohani, A. (2003). Income tax non-compliance in Malaysia. Petaling Jaya: Prentice Hall.

Othman, A. \& Mirakhor, A. (2012). Sustainable fiscal position Malaysia: A proposal for reform. $2^{\text {nd }}$ ISRA Colloquium. "Islamic Finance in a Challenging Economy: Moving Forward". Mohd Rashid, S. N. \& Shaik Asgar, R. K. B. (2014). Study on the possible impact of GST towards Malaysia using selected economic indicators: Case of Singapore, Thailand and 
Indonesia as model countries. International Conference on Business and Economic Research Proceeding. Sarawak, Malaysia.

Palil, M. R. \& Ibrahim, M. A. (2011). The impacts of goods and services tax (GST) on middle income earners in Malaysia. World Review of Business Research, 1(3), 192-206.

Sapiei, M. A. \& Abdullah, M. (2015). Veerinder on Malaysia tax theory and practice. 3th Edition, Malaysia: Wolters Kluwer.

Singh, V. (2013). Tax compliance and ethical decision making: A Malaysian perspective. Petaling Jaya: Longman.

Syed, M. A. T., Amit, K. S. \& Ravindra, K. S. (2013). Challenges and opportunities of goods and service tax (GST) in India. Indian Journal of Applied Research, 3(5), 413-415.

Tan, L. M. \& Chin-Fatt, C. (2000). The impact of tax knowledge on the perception of tax fairness and attitudes towards compliances. Asian Review of Accounting, 8, 44-58.

The Star Online (2015). Take stern action against profiteers, March 7.

The Star Online (2015). GST - Show me the money, show us our money, April 25.

The Star Online (2015). With GST, 295 products should be cheaper, May 12.

Valadkhani, A. \& Layton, A. P. (2004). Quantifying the effect of the GST on inflation in Australia's capital cities: An intervention analysis. Australian Economic Review, 37(2), $125-$ 138.

Whalley, J. \& Fretz, D. (1990). The economics of the goods and services tax. Canadian Tax Paper, 88.

Xing, W. \& Whalley, J. (2014). The golden tax project, value-added tax statistics and the analysis of internal trade in China. China Economic Review, 30, 448-468.

Zhang, Y. \& Huang, J. H. (2014). Cost-based pricing model with value-added tax and corporate income tax for a supply chain network. Applied Mathematical Modelling, 38, 268-280.

Zhou, L. Z., Tam, J. \& Heng-Contaxis, J. (2013). The Introduction of Goods and Services Tax in Malaysia: A Policy Analysis. Centre for Public Policy Studies (CPPS) Policy Paper Series, Asian Strategy \& Leadership Institute. 